\title{
Handwashing among Schoolchildren in Jatinangor, West Java
}

\author{
Cheryl May Chong Sue Faye, ${ }^{1}$ Chrysanti Murad, ${ }^{2}$ Sharon Gondodiputro ${ }^{3}$ \\ ${ }^{1}$ Faculty of Medicine Universitas Padjadjaran, ${ }^{2}$ Department of Microbiology and Parasitology, \\ Faculty of Medicine, Universitas Padjadjaran, ${ }^{3}$ Department of Public Health, Faculty of Medicine, \\ Universitas Padjadjaran
}

Abstract

Background: Diarrhea and pneumonia accounts for an estimated $40 \%$ of all child deaths around the world each year. Handwashing with soap could protect about 1 out of every 3 young children who get sick with diarrhea and almost 1 out of 6 young children with respiratory infections like pneumonia. Although people around the world clean their hands with water, very few use soap to wash their hands. Washing hands with soap removes germs much more effectively. This study was undertaken to determine the level of knowledge and practice regarding proper handwashing among elementary school children.

Methods: A descriptive study was conducted from August to October 2014 in Jatinangor using primary data from respondents who are 5th graders from four schools. A total of 49 males and 50 females were chosen using cluster random sampling. Schoolchildren who were present, able and well were given questionnaires after written informed consent was obtained from the schoolchildren and their guardians. Then, respondents demonstrated hand-washing techniques which were evaluated using a checklist.

Results: Overall, $52 \%$ of the schoolchildren had moderate level of hand -washing knowledge and $66 \%$ had bad handwashing practices.

Conclusions: Despite having a moderate level of handwashing knowledge, the majority still had poor handwashing practices. Handwashing programs should be carried out extensively to improve knowledge and practice. [AMJ.2016;3(2):170-4]

Keywords: Handwashing, knowledge, practices, schoolchildren

\section{Introduction}

Handwashing is the simplest, most effective measure for preventing the spread of bacteria, pathogens, and viruses. ${ }^{1}$ People frequently touch their eyes, nose, and mouth without even realizing it. Germs can enter the body through the eyes, nose and mouth and make us sick. ${ }^{2}$ Diarrhea and pneumonia accounts for an estimated $40 \%$ of all child deaths around the world each year. ${ }^{3}$ Handwashing has proven to be a cornerstone in preventing diarrheal infections. ${ }^{4}$ Handwashing with soap could protect about 1 out of every 3 young children who get sick with diarrhea and almost 1 out of 6 young children with respiratory infections like pneumonia. ${ }^{5}$ Although people around the world clean their hands with water, very few use soap to wash their hands. Washing hands with soap removes germs much more effectively. ${ }^{6}$
However, many do not practice the habit of correct handwashing techniques with soap in their daily life. In Indonesia, only $47 \%$ of the entire general public had correct handwashing habits which is usually only performed before eating and after defecating. ${ }^{7}$ This is still less than half of the entire Indonesian population. This study was undertaken to determine the level of knowledge and practice regarding proper handwashing among elementary schoolchildren.

\section{Methods}

An observational descriptive study was carried out from August to October 2014 in elementary schools (Sekolah Dasar/SD) located in Jatinangor West Java. The samples were taken using cluster random sampling from 28 schools that made up a total of 8.746 schoolchildren. Out of this number, four

Correspondence: Cheryl May Chong Sue Faye, Faculty of Medicine, Universitas Padjadjaran, Jalan Raya BandungSumedang Km.21, Jatinangor, Sumedang, Indonesia, Phone: +62 87822004679, Email: cherylmaychong@gmail.com 
schools were selected, namely SD Neglasari, SD Cikuda, SD Sayang and SD Cipacing I.

Next, randomization was performed only to fifth grade schoolchildren and 25 schoolchildren were selected randomly from each school. These schoolchildren were then given an informed consent form to be filled out by their parents or guardians. The selection criteria were based on the respondents' willingness to participate in this study. Schoolchildren who were absent on the day data was collected and those who did not complete the questionnaire appropriately were excluded from the study. In the end, 99 samples were obtained, comprising 49 males and 50 females.

After a brief introduction, they were given validated open-ended questionnaires, to be filled out. The questionnaire consisted of six questions about whether they were washing their hands, from whom they learned to wash their hands, the frequency of handwashing a day, when they washed their hands and also the reasons for washing their hands and the benefits of it. After filling out the questionnaire, the schoolchildren were then asked to perform handwashing steps and were evaluated using a checklist. Data from the students were then keyed into the Windows Excel and classified into gender and answers based on each question to identify the frequency and percentage for the questions. The answers were then categorized according to Arikunto's level of knowledge, which are good 76-100\%; moderate $56-75 \%$, and poor $40-55 \% .8$ In support of the checklist, the data were classified into each step carried out by the schoolchildren to identify the frequency and percentage. Only all handwashing steps which were carried out $100 \%$ correctly were considered good, less than that was considered otherwise. The Health Research Ethics Committee of the Faculty of Medicine, Universitas Padjadjaran has approved this study.

\section{Results}

This study was grouped based on the characteristics of respondents by gender. According to the collected data, the respondents were $50.51 \%$ female and $49.49 \%$ male.

The overview of level of proper handwashing knowledge among elementary schoolchildren showed that only $4.04 \%$ had good level of handwashing knowledge, while the majority of $51.52 \%$ had moderate level of handwashing knowledge, and $44.44 \%$ had poor level of handwashing knowledge (Table

Table 1 Overview of Level of Proper Handwashing Knowledge among Elementary Schoolchildren

\begin{tabular}{lcc}
\hline Knowledge & Frequency & Percentage \\
\hline Good & 4 & 4.04 \\
Moderate & 51 & 51.52 \\
Poor & 44 & 44.44 \\
Total & 99 & 100 \\
\hline
\end{tabular}

Table 2 Questionnaire Results for Level of Proper Handwashing Knowledge Assessment

\begin{tabular}{llcccc}
\hline \multirow{2}{*}{ No } & \multicolumn{1}{c}{ Questionnaire } & \multicolumn{2}{c}{ Adequate } & \multicolumn{2}{c}{ Inadequate } \\
\cline { 3 - 6 } & & $\mathrm{f}$ & $\%$ & $\mathrm{f}$ & $\%$ \\
\hline 1 & Like to wash hands & 99 & 100.00 & 0 & 0.00 \\
2 & Learn to wash hands from & 95 & 95.96 & 4 & 4.04 \\
3 & Frequency of handwashing & 4 & 4.04 & 95 & 95.96 \\
4 & Handwashing performed before and after & 0 & 0.00 & 99 & 100.00 \\
5 & Reason for washing hands & 96 & 96.97 & 3 & 3.03 \\
6 & Benefit of handwashing & 56 & 56.57 & 43 & 43.43 \\
\hline
\end{tabular}


Table 3 Overview of Level of Practice Regarding Proper Handwashing

\begin{tabular}{|c|c|c|}
\hline Practice & Frequency & Percentage \\
\hline Good & 34 & 34.34 \\
\hline Poor & 65 & 65.66 \\
\hline Total & 99 & 100 \\
\hline
\end{tabular}

Table 4 Handwashing Practice Performed by Schoolchildren

\begin{tabular}{llcccc}
\hline \multirow{2}{*}{ No } & \multirow{2}{*}{ Step by Step Handwashing Practices } & \multicolumn{2}{c}{ Yes } & \multicolumn{3}{c}{ No } \\
\cline { 3 - 6 } & & $\mathrm{f}$ & $\%$ & $\mathrm{f}$ & $\%$ \\
\hline 1 & Wet hands with running water & 98 & 98.99 & 1 & 1.01 \\
2 & Apply soap & 80 & 80.81 & 19 & 19.19 \\
3 & Lather hands & 99 & 100.00 & 0 & 0.00 \\
4 & Rub back of hand & 99 & 100.00 & 0 & 0.00 \\
5 & Rub between fingers & 98 & 98.99 & 1 & 1.01 \\
6 & Scrub under nails & 41 & 41.41 & 58 & 58.59 \\
7 & Perform steps 4-6 for both hands & 34 & 34.34 & 65 & 65.66 \\
8 & Scrub for 20 seconds & 94 & 94.95 & 5 & 5.05 \\
9 & Rinse under running water & 96 & 96.97 & 3 & 3.03 \\
10 & Dry hands using clean towel & 97 & 97.98 & 2 & 202 \\
\hline
\end{tabular}

1).

Furthermore, based on the result of level of proper handwashing knowledge assessment, it showed that all elementary schoolchildren in Jatinangor performed handwashing. However, $43 \%$ of the respondents did not know the benefits of handwashing (Table 2).

Moreover, only $34,34 \%$ of the respondents had good handwashing practices while the other $65,66 \%$ had poor practices of proper handwashing (Table 3).

Based on the result regarding handwashing practices among elementary schoolchildren through assessing the steps during handwashing, it showed that all respondents or $100 \%$ were always rubbing the back of their hands. Meanwhile, as many as $58.59 \%$ did not scrub under the nails and $19.19 \%$ did not apply soap (Table 4).

\section{Discussion}

This study demonstrated a moderate level of knowledge regarding proper handwashing among elementary schoolchildren. However, this study also showed that most children had poor practice of handwashing.
Regarding the first question, most children answered yes, when asked if they performed handwashing. While a small number answered only sometimes, the researcher accepted this answer as adequate as a person's likes and dislikes are the nature of a person.

The study found that most schoolchildren stated parents as their source of knowledge for learning handwashing however; some also added that doctors and teachers had taught them. This showed the importance of role model figures within a community in promoting good health practices. Moreover, parents, close family members and teachers play the most important role as schoolchildren spend most of their time at home and in school. Those whom were unable to answer this question probably lacked the role model figures in their upbringing, thus affecting their knowledge.

The answers on how often schoolchildren washed their hands a day, showed that the majority washed their hands less than 8 times a day. Based on the interpretation of CDC's criteria $^{3}$ when handwashing should be carried out, a person should wash hands at least 8 times a day, considering that handwashing should be 
carried out at least, before and after each meal, and after using the toilet. Even though CDC did not specify washing hands after a meal, in this study it was taken into consideration as most Indonesian people eat with their hands. Therefore, washinghands after meals should be accounted for in the frequency of handwashing a day. The data showed that many schoolchildren did not wash their hands as often as they should. Those who did not wash their hands at least 8 times a day were considered to have inadequate knowledge.

The study also found that most children washed their hands before and after meals but only a small group reported washing their hands after hands were visibly dirty, after using the toilet, and on top was washing their hands before and after meals. While all answers might be correct, the researcher considered the answers to be inadequate. According to CDC's specific activities which required handwashing are: the respondents should wash their hands before meals, after using the toilet, after playing and whenever their hands are visibly dirty, at the very least. ${ }^{3}$

Additionally, most schoolchildren knew the reasons for washing their hands. Their answers were considered to be adequate in this study. However, when asked about the benefits of handwashing, almost half of them were unable to answer.

The study found that despite having a moderate level of knowledge regarding handwashing, the schoolchildren had poor handwashing practices. Most of them did not perform the handwashing steps correctly; they especially omitted scrubbing under their nails. This condition was supported by observation findings which discovered that $28.28 \%$ of respondents had fingernails that were mostly dirty and long, while another $7.07 \%$ had short but dirty fingernails. Even, if handwashing was performed frequently, these children with dirty fingernails were still at risk of getting ill due to dirt under their nails. Therefore, educating children to keep their nails short is an important step. Scrubbing under their nails each time they wash their hands can help remove dirt and especially reduce parasitic infections. ${ }^{1,9}$ There were also a notable number of schoolchildren who did not apply soap and some did not wash their hands for at least 20 seconds. Some did not rinse their hands and few did not dry their hands with a towel. These findings could be due to lack of handwashing resources in their homes and schools such as soap and hand towel for drying their hands. ${ }^{10}$

Further factors that could influence the schoolchildren's handwashing practices include poor facilities within school compounds. ${ }^{11}$ The schools did not have a canteen or a proper place for the schoolchildren to eat during their break time. If such a place was provided with handwashing facilities, it can motivate and encourage more children to wash their hands frequently and at appropriate times. ${ }^{12}$

From observations conducted in this study, the schools did not have clean toilets and proper handwashing facilities. This could be a factor that hinders schoolchildren from carrying out better handwashing practices. ${ }^{12}$ Adequate water and sanitation as part of a healthy school environment can significantly improve a child's prospects to progress and flourish. ${ }^{13}$

Based on the analysis of data and discussions, the conclusion that can be made is that most of the elementary schoolchildren in Jatinangor, as many as $52 \%$ has moderate level of knowledge regarding proper handwashing and as many as $66 \%$ performs poor practices regarding proper handwashing.

There were some limitations that the researcher encountered during this study. The researcher was unable to conduct individual interviews with the respondents as most respondents were very shy and preferred to write their answers in the questionnaire. The questionnaire also should contain more questions to enhance measuring the knowledge and practice of handwashing among schoolchildren.

Based on this study, the government should encourage handwashing resources and facilities at homes and in schools. Handwashing practices could also be instilled by integrating handwashing education in schools as a part of extra-curriculum activities. Additionally, teachers should encourage handwashing practices in schools through peer-to-peer education, since teachers play an important role in instilling good handwashing practices as children spend many hours each day in school. ${ }^{14}$ As a whole, handwashing practices should be promoted through various health and community programs for schoolchildren and their families and thus, help improve the health status in communities. ${ }^{15}$

\section{References}

1. Centers for Diseases Control and Prevention.Vessel sanitation program: general information on hand hygiene. National Center for Environmental Health, 
Division of Emergency and Environmental Health Services: Atlanta, USA; 2009.

2. Bauman RW. Microbiology: with diseases by body system. New York, USA: Pearson; 2012.

3. Centers for Diseases Control and Prevention. Handwashing: clean hands save lives. CDC: Atlanta; 2013.

4. Tambekar D, Shirsat S. Hand washing: a cornerstone to prevent the transmission of diarrhoeal infection. Asian J Med Sci. 2009;1(3):100-3.

5. Rabie T, Curtis V. Handwashing and risk of respiratory infections: a quantitative systematic review. Trop Med Int Health. 2006;11(3):258-67.

6. Burton M, Cobb E, Donachie P, Judah G, Curtis V, Schmidt WP. The effect of handwashing with water or soap on bacterial contamination of hands. Int J Environ Res Public Health. 2011;8(1):97104.

7. Badan Penelitian dan Pengembangan Kesehatan Kementerian Kesehatan RI. Hasil Riset Kesehatan Dasar (RISKESDAS) 2013. Jakarta: Badan Penelitian dan Pengembangan Kesehatan Kementerian Kesehatan RI ; 2013.

8. Arikunto PDS. Prosedur penelitian: suatu pendekatan praktik. Revision ed. Jakarta: Rineka Cipta; 2010.

9. Shrestha A, Narayan K, Sharma R. Prevalence of intestinal parasitosis among school children in Baglung District of Western Nepal. Kathmandu Univ Med J
(KUMJ). 2012;10(37):62-5.

10. Saboori S, Greene LE, Moe CL, Freeman MC, Caruso BA, Akoko D, et al. Impact of regular soap provision to primary schools on hand washing and E. coli hand contamination among pupils in Nyanza Province, Kenya: a cluster-randomized trial. Am J Trop Med Hyg. 2013;89(4):698-708.

11. Setyautami T, Sermsri S, Chompikul J. Proper hand washing practices among elementary school students in Selat subdistrict, Indonesia. J Pub Health Dev. 2012;10(2):3-20.

12. Jasper C, Le T-T, Bartram J. Water and sanitation in schools: a systematic review of the health and educational outcomes. Int J Environ Res Public Health. 2012;9(8):2772-87.

13. Bowen A, Agboatwalla M, Luby S, Tobery T, Ayers T, Hoekstra RM. Association between intensive handwashing promotion and child development in Karachi, Pakistan: a cluster randomized controlled trial. Arch Pediatr Adolesc Med. 2012;166(11):103744.

14. Rosen L, Zucker D, Brody D, Engelhard D, Manor O. The effect of a handwashing intervention on preschool educator beliefs, attitudes, knowledge and self-efficacy. Health Educ Res.2009;24(4):686-98.

15. Luby SP, Agboatwalla M, Feikin DR, Painter J, Billhimer W, Altaf A, et al. Effect of handwashing on child health: a randomised controlled trial. Lancet. 2005;366(9481):225-33. 